\title{
FIRST SPECIES OF PARAGALENE KOSSMANN, 1878 (DECAPODA, BRACHYURA, PROGERYONIDAE) FROM THE WESTERN ATLANTIC
}

\author{
BY \\ MARCOS TAVARES ${ }^{1,2}$ ) and GUSTAVO A. S. DE MELO ${ }^{1,3}$ ) \\ 1) Museu de Zoologia, Universidade de São Paulo, Ipiranga 04263-000, São Paulo, SP, Brazil
}

\begin{abstract}
A new species of deep-water crab, Paragalene danieleae (Progeryonidae), from the western Atlantic is described and illustrated. The new species can be easily separated from its eastern Atlantic and Mediterranean counterpart, P. longicrura (Nardo, 1868), by a suite of carapace and appendage characters.
\end{abstract}

\section{RÉSUMÉ}

Une nouvelle espèce de crabe d'eau profonde, Paragalene danieleae (Progeryonidae) de l'Atlantique occidental est décrite et illustrée. La nouvelle espèce se sépare aisement de sa analogue de l'Atlantique oriental et Mediterranée, P. longicrura (Nardo, 1868), par divers caractères de la carapace et des appendices.

\section{INTRODUCTION}

For more than thirteen decades Paragalene longicrura (Nardo, 1868) has been the only valid species assigned to the genus Paragalene Kossmann, 1878. Paragalene longicrura is rare and has been known only from a small number of localities in the Mediterranean Sea and two localities in the eastern Atlantic (see d'Udekem d'Acoz, 1999). Its taxonomic position has long been controversial. The species was originally described in the genus Eriphia Latreille, 1817, and accordingly attributed to the Xanthidae (Nardo, 1868). It was later included in the Geryonidae (e.g., Guinot, 1969: 692, 696; 1971:

\footnotetext{
2 ) Corresponding author: e-mail: mdst@usp.br

3) e-mail: gasmelo@usp.br 
1077-1078; Türkay, 1976a, b), until Manning \& Holthuis (1989) restricted the Geryonidae to Geryon Krøyer, 1897, Chaceon Manning \& Holthuis, 1989, and Zariquieyon Manning \& Holthuis, 1989. Manning \& Holthuis (1989: 51) also suggested that Paragalene could be included in a family of its own, along with Progeryon Bouvier, 1922. Instead of dealing with the uncertain taxonomic position of Paragalene as well as Progeryon, Števčić (2005: 64) erected two intermediate categories, the redundant monotypic tribes Paragalenini Števčić, 2005, and Progeryonini Števčić, 2005, both included in the Geryoninae (Geryonidae). Karasawa \& Schweitzer (2006) attributed full family status to the Progeryonini (as Progeryonidae), to which Paragalene was eventually transferred (Ng \& Manuel-Santos, 2007; Ng et al., 2008).

Trapping operations recently conducted between 100 and $1000 \mathrm{~m}$ depth off the coast of Guadeloupe, West Indies, revealed a wealth of diversity of decapod crustaceans (Poupin, 1994; Tavares, 1994; Tavares \& Guinot, 1996), and among them a western Atlantic counterpart of P. longicrura, herein described as new, Paragalene danieleae $\mathrm{n}$. sp.

The following abbreviations are used: CBR (Colleccions Biològiques de Referència, Institut de Ciències del Mar, Barcelona); MZUSP (Museu de Zoologia, Universidade de São Paulo); cl, carapace length; cw, carapace width; P1, cheliped; P2-P5, pereiopods 2 to 5.

\section{SYSTEMATIC ACCOUNT}

\section{Family ProgeryonidAe Števčić, 2005}

\section{Paragalene Kossmann, 1878}

Paragalene Kossmann, 1878: 253.

Type species. - Paragalene neapolitana Kossmann, 1878, by monotypy [=Eriphia longicrura Nardo, 1868]. Gender feminine.

Species included. - Paragalene longicrura (Nardo, 1868), eastern Atlantic and Mediterranean Sea (d'Udekem d'Acoz, 1999: 241, and references therein); Paragalene danieleae n. sp., western Atlantic.

\section{Paragalene danieleae n. sp. (figs. 1, 3A, C)}

Type material. - Holotype: female (cl 37 mm, cw 48 mm) (MZUSP 19938), Caribbean Sea, West Indies, Guadeloupe, west coast of Basse Terre, Mission ORSTOM-IRPM-SMCB, stn A210, $16^{\circ} 11.80^{\prime} \mathrm{N} 61^{\circ} 48.72^{\prime}$ W, G. Leblond and J. Poupin leg., April 1993, $250 \mathrm{~m}$. 
Comparative material. - Paragalene longicrura (Nardo, 1868), western Mediterranean Sea, Balearic Is., Cape Freu, northeastern Mallorca, $39^{\circ} 45^{\prime} \mathrm{N} 03^{\circ} 26^{\prime} \mathrm{E}$, La Salada cave, 1984, approximately $10 \mathrm{~m}, 1$ female (cl $40 \mathrm{~mm}$, cw $55 \mathrm{~mm}$ ) (CBR).

Etymology. - The new species is named after our colleague and friend Danièle Guinot (Muséum national d'Histoire naturelle, Paris), whose carcinological oeuvre changed our understanding of brachyuran systematics worldwide.

Description of holotype female. - Carapace subpentagonal, slightly wider than long, $\mathrm{cl} / \mathrm{cw}$ ratio 1.29 (figs. 1C, 3A). Front cut into 4 lamellar teeth, 2 mesial, 2 lateral, inner orbital teeth excluded. Median notch between mesial rostral teeth distinctly U-shaped; distance between mesial rostral teeth markedly greater than distance between mesial rostral tooth and lateral rostral

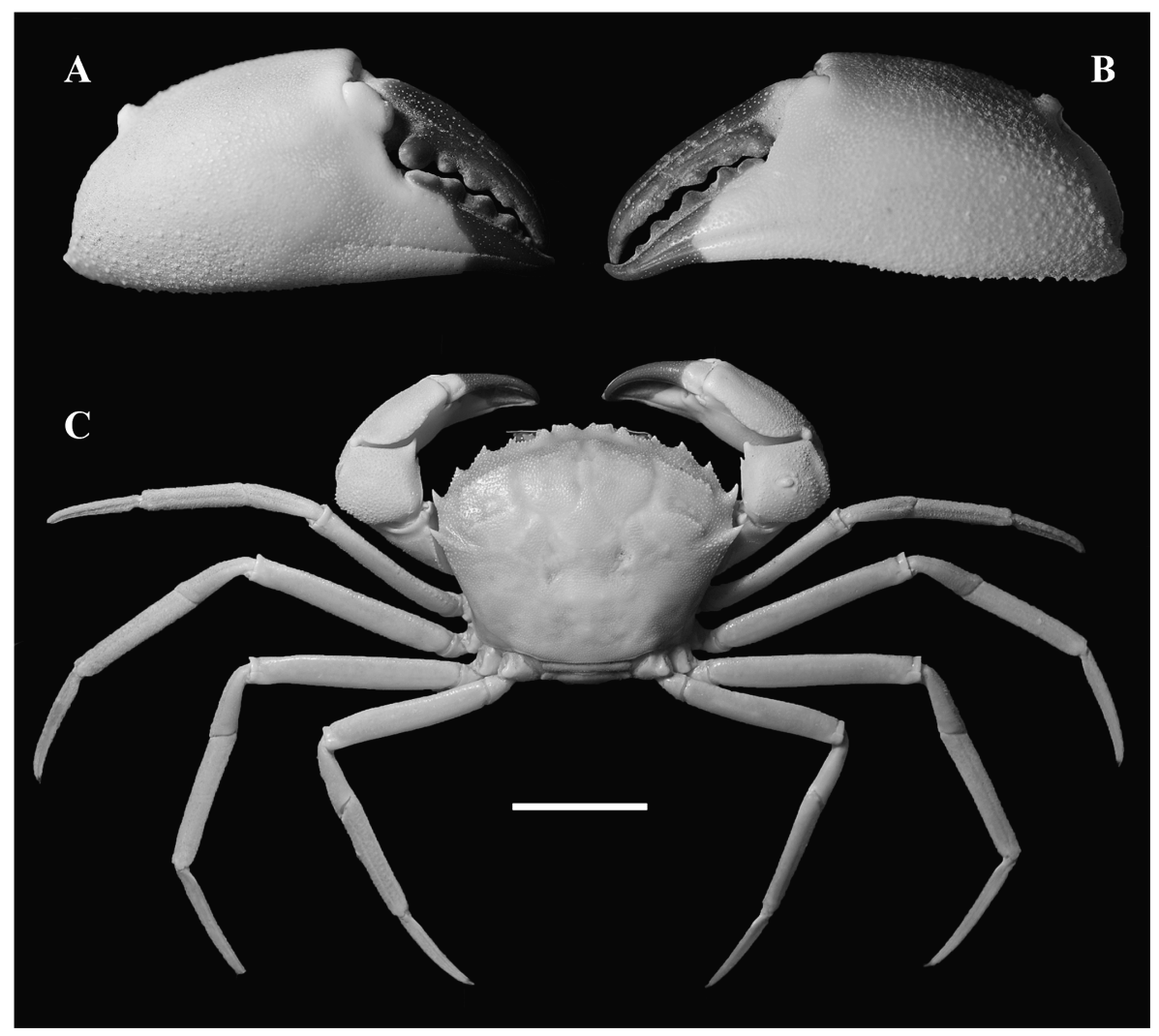

Fig. 1. Paragalene danieleae n. sp. female holotype cl 37 mm, cw 48 mm (MZUSP 19938). A, B, right and left cheliped propodus and dactylus, respectively; C, habitus, dorsal view. Scale bar: $20 \mathrm{~mm}$. 
tooth. Orbit circular, deep. Supraorbital border entire, narrow, semicircular, with large granules (figs. 1C, 3C). Inner supraorbital tooth triangular, stronger than outer tooth; inner suborbital tooth acute, much stronger than outer suborbital tooth. Infraorbital border incomplete. First antennal article short, mobile; article $2+3$ closing infraorbital border; fourth longer than $2+3$, reaching supraorbital border; fifth slender, oblique. Ocular peduncle short, cornea well formed, dark brown pigmented. Carapace anterolateral borders curved, each armed with 4 anterolateral teeth, outer supraorbital excluded. First, second teeth sharp, well defined; third anterolateral tooth strongest, acute, curved forward; fourth straight, outwardly directed, smooth acute apex. Posterolateral borders straight. Carapace dorsal surface strongly convex anteriorly, granules much larger, dense anteriorly. Granular ridge across hepatic region almost straight, well marked; granular ridge across mesobranchial region shorter. Protogastric region with 2 weak, granular elevations, shallowly grooved medially. Urogastric region sided by distinct depression. Cardiac region slightly elevated, finely granular. Anterior border of buccal cavern smooth, prominent, clearly demarcating epi- and endostome; endostomial ridge strong, smooth. Third maxillipeds completely closing buccal frame; palp long, overreaching ischio-meral suture; anterolateral angle of merus expanded, wing-like; ischium much longer than merus.

Chelipeds (P1) moderately heterochelic, heterodont. Right cheliped strongest, massive. Dactylus slender, less than half propodus maximal length, dark brown coloured; cutting edge with strong, rounded proximal tooth, remaining teeth low (fig. 1A-C). Dorsal, lateral, ventral faces of propodus finely granular, mesial face smooth; carpus granular, with 2 acute teeth on inner margin, superior tooth much stronger than inferior. Left P1 distinctly less massive; dactylus, pollex slender, proximal tooth on cutting edge of dactylus lacking, left P1 otherwise similar to right cheliped. P2-P5 markedly long, slender, similar in shape (fig. 1C). Dactyli similar in shape, slightly curved, acute; upper, ventral surfaces densely setose; mesial, lateral surfaces, and tip devoid of setae. Dactyli of P2, P5 similar in size, distinctly shorter than those of P3, P4. Meri, carpi, propodi long, slender, similar in shape. Meri of P2, P5 similar in size, distinctly shorter than those of P3, P4; distal end of merus of P5 extending far beyond tip of the last anterolateral carapace tooth.

Female thoracic sternum wide, sterno-abdominal cavity shallow, formed by sternites 8 -4. Sternal suture $2 / 3$ distinct, uninterrupted; $3 / 4$ faint, recognizable laterally only; $4 / 5,5 / 6$ deep, medially interrupted; $6 / 7,7 / 8$ deep, complete. 
Female abdomen with 6 freely-movable somites plus telson. Somites 1, 2 completely covering thoracic sternum between P5 coxae, thoracic sternite 8 not visible; somite 3 very close to margin of sternite 7, small portion of thoracic sternite 7 visible only laterally. Abdominal somite 6 longest. Telson large, little wider than long, extending from thoracic sternite 5 to sternal sutures $2 / 3$. Vulvae small, completely covered by abdominal somite 6 , opening near thoracic sternal suture $5 / 6$.

Male unknown.

Remarks. - Paragalene was until now known from one species, P. longicrura from the eastern Atlantic (Madeira and Canary Islands: Türkay, 1976a, b; González Pérez, 1995) and the Mediterranean Sea (Bouvier, 1940; Dieuzeide \& Goëau-Brissonnière, 1955; Guinot, 1969; Gili \& Macpherson, 1987; d'Udekem d'Acoz, 1999; Pallaoro, 2005; Castro \& Ng, 2008; Ng et al., 2008). Paragalene longicrura occurs in dark caves and on hard bottoms with algal growth and shells, at depths between 30 and $160 \mathrm{~m}$, and is considered to be rare (see d'Udekem d'Acoz, 1999: 241). The discovery of a congener, $P$. danieleae n. sp., after thirteen decades is quite a surprise. Although Paragalene danieleae n. sp. is represented by only one adult female, it can be easily distinguished from P. longicrura (figs. 2, 3B, D) by: (1) distal end of P5 merus extending far beyond the tip of the last (fourth) anterolateral carapace tooth (almost reaching to the tip of the tooth in P. longicrura); (2) distal end of merus of P4 extending far beyond the imaginary line connecting the tips of the third anterolateral carapace teeth (slightly overreaching that line in P. longicrura); (3) median notch between mesial rostral teeth clearly U-shaped (distinctly V-shaped in P. longicrura); (4) distance between the two mesial rostral teeth markedly greater than the distance between one mesial rostral tooth and its adjacent lateral rostral tooth (distance between mesial and adjacent lateral rostral teeth about the same in $P$. longicrura); (5) second anterolateral tooth sharp, well defined (broadly triangular in P. longicrura); (6) granular ridge across the hepatic region almost straight (distinctly convex in $P$. longicrura); (7) convexity of gastric regions of carapace more pronounced (gastric regions only slightly convex in P. longicrura); and (8) carapace subpentagonal, $\mathrm{cl} / \mathrm{cw} 1.29$ (carapace hexagonal, proportionally wider in relation to its length in $P$. longicrura, $\mathrm{cl} / \mathrm{cw} \mathrm{1.37).} \mathrm{The}$ above differences refer to the females only. These characters, however, are not known to vary between sexes (see also Castro \& $\mathrm{Ng}$, 2008) so the differences clearly suggest the West Atlantic species is new. The discovery of the male of 


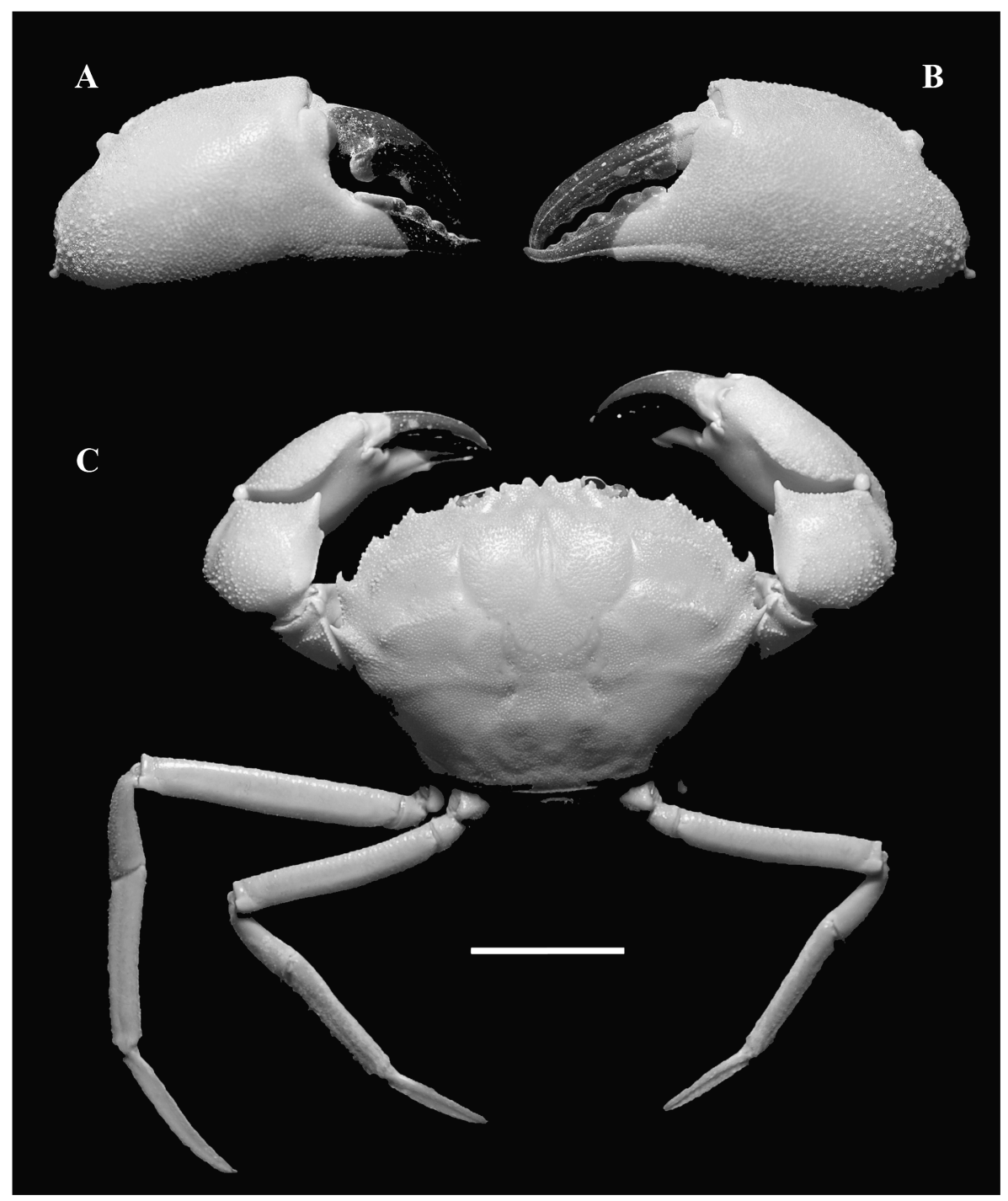

Fig. 2. Paragalene longicrura (Nardo, 1868) female cl 40 mm, cw $55 \mathrm{~mm}$ (CBR unnumbered). A, B, right and left cheliped propodus and dactylus, respectively; C, habitus, dorsal view. Scale bar: $20 \mathrm{~mm}$.

P. danieleae n. sp. will permit additional taxonomic details to be added to the original description and probably show additional differences between the two species.

Distribution. - Known so far from the type locality, Guadeloupe in the Caribbean Sea. 


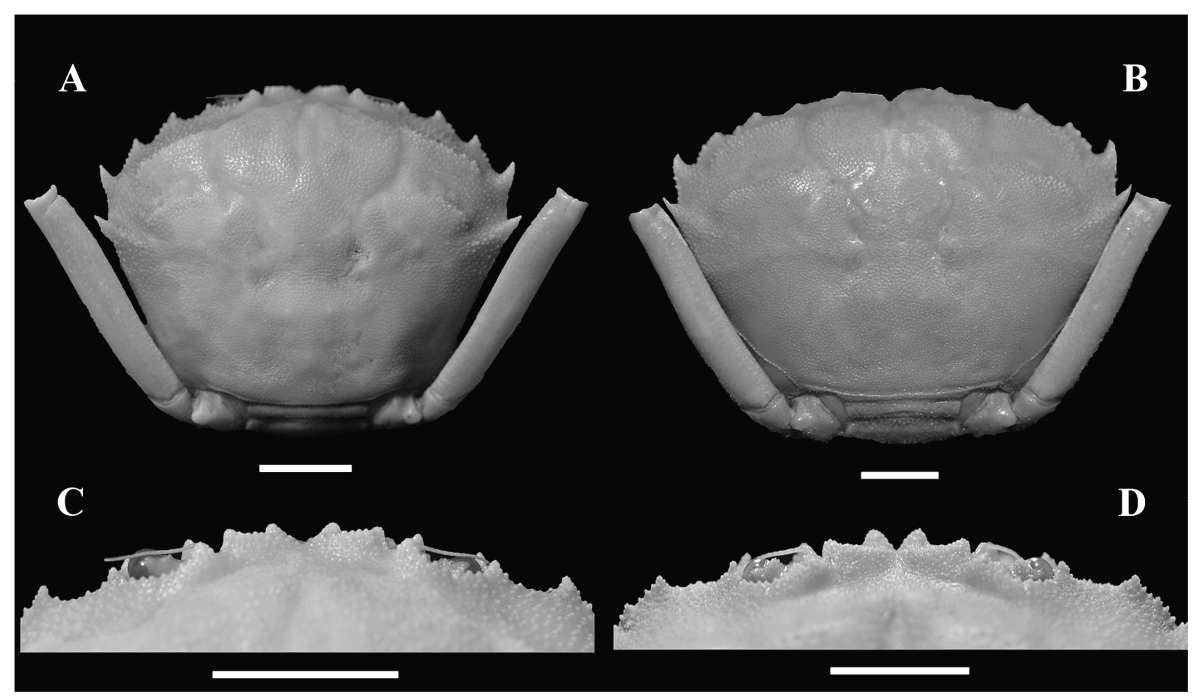

Fig. 3. A, C, Paragalene danieleae n. sp. female holotype cl $37 \mathrm{~mm}$, cw $48 \mathrm{~mm}$ (MZUSP 19938). B, D, Paragalene longicrura (Nardo, 1868) female cl $40 \mathrm{~mm}$, cw $55 \mathrm{~mm}$ (CBR unnumbered). A, B, dorsal view of carapace and merus of pereiopod 5; part of pereiopod 5 and remaining appendages removed electronically from figure; $\mathrm{C}, \mathrm{D}$, anterior border of carapace. Scale bars: $10 \mathrm{~mm}$.

\section{ACKNOWLEDGEMENTS}

We thank the editors for the opportunity to contribute to this special volume. This contribution would not have been possible without the help of our colleagues and friends Enrique Macpherson (Consejo Superior de Investigaciones Cientificas and Centre d'Estudis Avancats de Blanes, Girona, Spain), who arranged the loan of Paragalene longicrura, and Joseph Poupin (Institut de Recherche de l'École Navale, BCRM-Brest, France), who made the material of $P$. danieleae n. sp. available for study. Thanks also to Allyson Pinheiro and William Santana (both from MZUSP) for preparing the photographs and plates, respectively. We also thank the CNPq (Conselho Nacional de Desenvolvimento Científico e Tecnológico, Brasília) for supporting studies on the systematics of decapod crustaceans in the form of ongoing grants 302065/2007-5 and 303224/87-8, respectively. MT thanks PETROBRAS for financial support (process number 4600224970).

\section{REFERENCES}

Bouvier, E.-L., 1940. Décapodes marcheurs. Faune de France, 37: 1-404. (Paul Le Chevalier, Paris). 
CAStro, P. \& P. K. L. NG, 2008. Rhadinoplax, a new genus of Progeryonidae Števčić, 2005 for Carcinoplax microphthalmus Guinot \& Richer de Forges, 1981, and a redescription of Paragalene longicrura (Nardo, 1868) (Crustacea: Decapoda: Brachyura: Goneplacoidea). Zootaxa, 1777: 53-68.

DieuzéIDe, R. \& W. GoËAU-Brissonnière, 1955. Paragalene longicrura Nardo (Décapode Brachyoure) aux environs d'Alger. Bulletin des Travaux de la Station d'Aquiculture et Pêche de Castiglione, (n. ser.) 7: 275-279.

Gili, J. M. \& E. MACPHERSON, 1987. Crustáceos decápodos capturados em cuevas submarinas del litoral Balear. Investigacion Pesquera, Bercelona, 51 (Supplement 1): 285-291.

GonZÁlez PÉreZ, J. A., 1995. Catálogo de los crustáceos decápodos de las Islas Canarias. Gambas, langostas, cangrejos: 1-281. (Publicaciones Turquesa, Santa Cruz de Tenerife).

Guinot, D., 1969. Les Goneplacidae (suite et fin). Recherches préliminaires sur les groupements naturels chez les Crustacés Décapodes Brachyoures. VII. Bulletin du Muséum national d'Histoire naturelle, Paris, (2) 41 (3): 688-724.

— —, 1971. Synthèse et bibliographie. Recherches préliminaires sur les groupements naturels chez les Crustacés Décapodes Brachyoures. VIII. Bulletin du Muséum national d'Histoire naturelle, Paris, (2) 42 (5): 1063-1090.

Karasawa, H. \& M. Schweitzer, 2006. A new classification of the Xanthoidea sensu lato (Crustacea: Decapoda: Brachyura) based on phylogenetic analysis and traditional systematics and evaluation of all fossil Xanthoidea sensu lato. Contributions to Zoology, 75 (1/2): 23-73.

Kossmann, R., 1878. Kurze Notizen über einige neue Crustaceen sowie über neue Fundorte einiger bereits beschriebenen. Archiv für Naturgeschichte, 44 (1): 251-258.

Manning, R. B. \& L. B. Holthuis, 1989. Two new genera and nine new species of geryonid crabs (Crustacea: Decapoda: Geryonidae). Proceedings of the Biological Society of Washington, 102 (1): 50-77.

NARDO, G. D., 1868. Annotazioni illustranti cinquantaquattro specie di Crostacei podottalmi, endottalmi e succhiatori del mare Adriatico, alcune delle quali nuove o male conosciute, accompagnate da trentare figure litografate, e precedute dalla storia della carcinologia Adriatica antica e rencente. Memorie del Reale Istituto Veneto di Scienze Lettere e Arti, Venezia, 14 (2): 217-343.

NG, P. K. L., D. Guinot \& P. J. F. Davie, 2008. Systema Brachyurorum: Part 1. An annotated checklist of extant brachyuran crabs of the world. Raffles Bulletin of Zoology, (Supplement) 17: 1-286.

NG, P. K. L. \& M. R. Manuel-Santos, 2007. Establishment of the Vultocinidae, a new family for an unusual new genus and new species of Indo-West Pacific crab (Crustacea: Decapoda: Brachyura: Goneplacoidea), with comments on the taxonomy of the Goneplacidae. Zootaxa, 1558: 39-68.

Pallaoro, A., 2005. The discovery of the crab, Paragalene longicrura (Nardo, 1868) (Decapoda, Brachyura, Xanthidae) in the Adriatic Sea. Crustaceana, 78 (6): 749-753.

PoupIN, J., 1994. Faune marine profonde des Antilles françaises. Récoltes du navire Polka faites en 1993: 1-79. (ORSTOM Éditions, Collection Études et Thèses, Paris).

ŠTEVČIĆ, Z., 2005. The reclassification of brachyuran crabs (Crustacea: Decapoda: Brachyura). Fauna Croatica, 14 (1): 1-159.

Tavares, M., 1994. Description de Cymonomus leblondi sp. nov. de la Guadeloupe, avec une clef des Cymonomus américains (Decapoda, Brachyura, Cymonomidae). Bulletin du Muséum national d'Histoire naturelle, Paris, (4) 16 (1): 203-208. 
TAVARes, M. \& Guinot, D., 1996. Description de Neopilumnoplax gervaini sp. nov. des eaux profondes des Caraïbes (Decapoda, Brachyura, Goneplacidae). Bulletin du Muséum national d'Histoire naturelle, Paris, (4) 18 (1-2): 225-232.

TÜrKaY, M., 1976a. Die Madeirensischen Brachyuren des Museu Municipal do Funchal und des Forschungs-Instituts Senckenberg. I. Familien: Dromiidae, Homolidae, Calappidae, Leucosiidae, Cancridae, Portunidae, Xanthidae, Geryonidae, Goneplacidae und Palicidae (Crustacea: Decapoda). Boletin du Museu Municipal do Funchal, 30 (133): 57-74.

— - 1976b. Ein Fund von Paragalene longicrura (Nardo, 1868) in der Ägäis (Decapoda: Brachyura). Crustaceana, 30 (1): 108.

UdeKem D'ACOZ, C. D', 1999. Inventaire des Crustacés Décapodes de l'Atlantique nordoriental, de la Méditerranée et des eaux continentales adjacentes au nord de $25^{\circ} \mathrm{N}$. Muséum national d'Histoire naturelle/Service du Patrimoine Naturel, Collection Patrimoines Naturels, Paris, 40: 1-383.

First received 26 June 2009.

Final version accepted 16 July 2009. 